
\author{
А. М. ПРОДАН ${ }^{2}$, Н. А. АЛЬ ДЖЕХАНІ \\ Рівненський державний гуманітарний університет ${ }^{1}$ \\ Тернопільський національний медичний університет імені І. Я. Горбачевського \\ Рівненська міська лікарня Рівненської міської ради
}

(СВ. М. АНТОНЮК-КИСІЛЬ ${ }^{1,3}$, І. Я. ДЗЮБАНОВСЬКИЙ², Є. Ф. КУЧЕРУК ${ }^{3}$, С. А. НЕВМЕРЖИЦЬКИЙ

\title{
Відкрита “офісна флебологія” первинного хронічного захворювання вен нижніх кінцівок
}

\begin{abstract}
Мета роботи: оцінити ефективність використання методики CHIVA у корекції венозної недостатності різного ступеня на принципах офісної хірургії.

Матеріали і методи. Проведено аналіз результатів відкритого хірургічного лікування 578 пацієнтів (21,45 \% - чоловіки та 78,55 \% - жінки) із первинним хронічним захворюванням вен нижніх кінцівок. Виділено дві групи пацієнтів, яким виконували планові втручання 423 (71,18 \%) хворі - 1 група та 155 (26,82 \%) пацієнтів в ургентному порядку - 2 група. Розподіл пацієнтів за тяжкістю первинного хронічного захворюванням вен проводили згідно з класифікацією CEAP (2020): C 2 - 355 (61,42 \%), C3s -

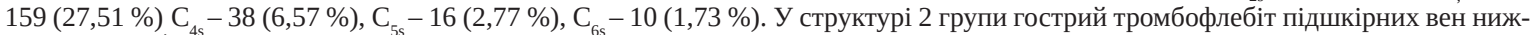
ніх кінцівок діагностовано у 143 (92,25 \%), кровотечу із варикозних вузлів - 12 (7,74 \%). Варикозний анамнез оперованих склав від 3 до 25 років (в середньому 10,4 × 5,8 року). Двобічний характер патології виявлено у 37,50 \% осіб, у 62,50 \% - однобічний, переважно на лівій нижній кінцівці. Ступінь клінічних проявів захворювання до та після перенесеного операційного втручання оцінювали за допомогою шкал (VCSS, VDS, VSS).

Результати досліджень та їх обговорення. Порівняльний аналіз результатів операційного лікування двох груп (ургентне та планове лікування) із первинним хронічним захворюванням вен нижніх кінцівок у динаміці методом СНIVA на принципах офісної хірургії засвідчив, що критерій VSDS нормалізувався в обох групах. Серед оперованих в плановому порядку цей показник становив 89,90 \% в ранньому післяопераційному періоді. Після проведеного ургентного хірургічного втручання у 78,30 \% пацієнтів відновлення працездатності проходило дещо повільніше з нормалізацією його в пізньому післяопераційному періоді. Згідно 3 критерієм VDS, серед оперованих у плановому порядку процес відновлення проходив швидше (96,40 \%) в ранньому післяопераційному періоді, а повне відновлення працездатності впродовж 3 тижнів встановлено у 89,70 \% оперованих пацієнтів. Згідно з критерієм VSDS патологічних венозних рефлюксів в системі підшкірних вен у ранньому і пізньому післяопераційних періодах не діагностовано в жодному випадку.
\end{abstract}

Ключові слова: первинне хронічне захворювання вен; CHIVA; офісна хірургія.

Постановка проблеми і аналіз останніх досліджень та публікацій. Первинне хронічне захворювання вен (ПХЗВ) нижніх кінцівок за кількістю хворих є однією із найбільш поширених патології поміж судинних захворювань, яке зустрічається у 20-70 \% населення розвинених країн, i $є$ особливо актуальною серед осіб працездатного віку [1]. Декомпенсовані форми даної патології найчастіше зустрічаються у старшій віковій групі в 1-2 \% населення з частотою 1,48-3,05 на 1000 населення [2].

Своєчасна санація хворих із первинним хронічним захворюванням вен нижніх кінцівок на ранніх стадіях захворювання економічними безпечними методиками в амбулаторних умовах $\epsilon$ дуже актуальною і потребує іï̈ практичного вирішення. Завдяки використанню єдиної уніфікованої термінології International Association for Ambulatory Surgery (IAAS) вдалося стандартизувати підходи до організації хірургічної флебологічної допомоги в амбулаторно-поліклінічній ланці - так звана офісна хірургія [3].
Розвиток сучасних неінвазивних, безпечних, доступних та високоінформативних методик діагностики, яким є дуплексне ультразвукове ангіосканування, підняло на більш якісний рівень дослідження анатомії та гемодинаміки венозної системи, що дало змогу активно впроваджувати методи амбулаторної консервативної гемодинамічної кореції венозної недостатності (CHIVA) [4-9].

Мета роботи: оцінити ефективність використання методики CHIVA у корекції венозної недостатності різного ступеня в амбулаторних умовах.

Матеріали і методи. Проведено аналіз результатів відкритого хірургічного лікування 578 пацієнтів (21,45 \% - чоловіки та 78,55 \% - жінки) з ПХЗВ нижніх кінцівок. Середній вік пацієнтів складав 41,0 \pm 8,4 року. Переважали хворі працездатного віку від 29 до 62 років (69,60 \%), яким в умовах операційної хірургічного відділення поліклініки № 1 КНЗ “Рівненської міської лікарні” виконано в період 2014-2021 pp. 578 операційних втручань. Виділено дві групи пацієнтів, яким ви- 
конували планові втручання 423 (71,18\%) хворих - 1 група та 155 (26,82 \%) пацієнтів в ургентному порядку - 2 група. Розподіл пацієнтів за тяжкість ПХЗВ проводили згідно 3 класифікацією СЕАР (2020): $\mathrm{C}_{2 \mathrm{~s}-}-355(61,42 \%) \mathrm{C} 3 \mathrm{~s}-159(27,51 \%) \mathrm{C}_{4 \mathrm{~s}}-$ 38 (6,57\%), $\mathrm{C}_{5 \mathrm{~s}}-16(2,77 \%), \mathrm{C}_{6 \mathrm{~s}}-10(1,73 \%)$ '[10].

Серед пацієнтів першої групи 62 (14,66 \%) оперовані з причини рецидиву ПХЗВ із відновленням клінічних проявів захворювання (істинний рецидив у 45 (7,79 \%) пацієнтів, не істинний - 17 (2,94 \%). В структурі 2 групи гострий тромбофлебіт підшкірних вен нижніх кінцівок діагностовано у 143 (92,25 \%) хворих, кровотечу із варикозних вузлів - 12 (7,74 \%) пацієнтів. Варикозний анамнез оперованних склав від 3 до 25 років (в середньомy 10,4 \pm 5,8 року). Двобічний характер патології виявлено у 37,50 \% осіб, у 62,50 \% - однобічний, переважно на лівій нижній кінцівці.

Використовували переважно 3 групи критеріїв при відборі пацієнтів на відкрите хірургічне лікування ПХЗВ в умовах офісної хірургії: загальномедичні - компенсований стан за основними супутніми захворюваннями за даними анамнезу, аналізу медичної документації та загальноклінічного обстеження; хірургічні - сонографічне сканування з обов'язковим картографуванням патологічних ділянок та маркування їх на шкірних покривах згідно з протоколом; соціальні - оцінка соціально-психологічного статусу пацієнта, відношення до виконання лікарських рекомендацій в амбулаторних умовах. В усіх пацієнтів отримано письмову згоду на проведення даного методу лікування. Ступінь клінічних проявів захворювання до та після перенесеного операційного втручання оцінювали за допомогою шкал (VCSS, VDS, VSS) [11].

Результати досліджень та їх обговорення. Сформований комплекс організаційних заходів, що забезпечував безпечність операційного втручання ПХЗВ за принципами “офісної хірургії” включав: персоналізований відбір хворих на хірургічне лікування та згода на лікування в амбулаторних умовах; вибір та обгрунтування хірургічної тактики з врахуванням різних анатомічних особливостях будови венозної системи і характеру порушень венозної гемодинаміки за даними сонографії; адекватна анестезія; обов'язкове та повне дотримання комплексу післяопераційних реабілітаційних заходів за межами стаціонару, що сприятиме безпечному перебігу післяопераційного періоду і отриманню тривалих позитивних результатів.

Операційні втручання проводили за методикою CHIVA [4] без класичної премедикації під тумесцентною анестезією з використанням підігрі- того до $25^{\circ} \mathrm{C}$ 0,25 \% розчину новокаїну в кількості 20-40 мл на один операційний розріз, без додавання розчину адреналіну. У пацієнтів із клінічними класами $\mathrm{C}_{2}-\mathrm{C}_{4}$ виконували високе перев'язування стовбура ВПВ і /або МПВ та їх гілок із розрізу у 2-3 см у точній проекції підшкірно-стегнового або підшкірно-підколінного співустя, без пересічення ïx, протягом 2-3 см 2-ма лігатурами із матеріалу, що не розсмоктується. Варикозно трансформовані венозні гілки видаляли за методикою мініфлебектомії за Мюллером. Неспроможні перфорантні вени, після їх чіткої верифікації за даними дуплексного ангіосканування, надфасціально перев'язували, без пересічення, нитками, що не розсмоктуються. Тривалість операційного втручання становила до 1 години. Операційне втручання завершували накладанням компресійних панчіх клас компресії 2 або еластичним бинтуванням.

У пацієнтів із трофічним розладами шкірних покривів гомілок, зумовлених венозною патологією, $\mathrm{C}_{5}-\mathrm{C}_{6}$ клас (дерматит, активні трофічні виразки до $\left.20 \mathrm{~cm}^{2}\right)$, планувалось операційне втручання у 2 етапи. На першому етапі виконували операційне втручання за межами трофічних розладів - високе перев'язування ВПВ і/або МПВ, надфасціальне перев'язування перфорантних вен, видалення варикозних конгломератів. Другим етапом після купірування явищ дерматиту, загоєння трофічних виразок (ультразвуковий дебридмент + PRP терапія) виконували контрольну сонографію. За наявності декомпенсованних перфорантних вен їх перев’язували. Потребували другого етапу серед 26 (4,50 \%) пацієнтів із клінічним проявами захворювання $\mathrm{C}_{5}, \mathrm{C}_{6}$ було 3 (0,51 \%) осіб.

У післяопераційному періоді серед оперованих загальносоматичних ускладнень, погіршення загального стану, супутніх захворювань не відмічено. Ранні післяопераційні ускладнення: 3,11 \% - сероми, 0,35 \% - нагноєння однієї із ран на гомілці, 0,35 \% - кровоточивість із рани у пацієнта, що отримував клопідогрель після стентування коронарних артерій.

Аналіз результатів виконували в ранньому (до 7 днів), пізньому (до 3 тижнів) та у віддаленому (до 12 місяців) періодах від проведеного хірургічного лікування (табл.).

Порівняльний аналіз результатів операційного лікування двох груп (ургентне та планове лікування) із ПХЗВ нижніх кінцівок у динаміці методом CHIVA на принципах офісної хірургії засвідчив, що критерій VSDS нормалізувався в обох групах. Серед оперованих у плановому порядку цей показник становив 89,90 \% у ранньому післяопераційному періоді. Після проведеного ургентного 
Таблиця. Динаміка показників шкал VCSS, VDS, VSDS у двох групах у різні терміни спостереження

\begin{tabular}{||c|c|c|c|c|c|c|c|c||}
\hline \multirow{2}{*}{ Шкали } & \multicolumn{4}{|c|}{1 група (планова операція) } & \multicolumn{4}{c||}{2 група (ургентна операція) } \\
(n=423) & \multicolumn{3}{|c|}{$(\mathrm{n}=115)$} \\
\cline { 2 - 10 } & 1 & 2 & 3 & 4 & 1 & 2 & 3 & 4 \\
\hline VCSS & $20.3 \pm 0.90$ & $16.2 \pm 0.11$ & $13.2 \pm 0.02$ & $10.4 \pm 0.01$ & $22.03 \pm 0.10^{*}$ & $16.1 \pm 0.03^{*}$ & $12.4 \pm 0.02 *$ & $10.4 \pm 0.05^{*}$ \\
\hline VDS & $2.45 \pm 0.25$ & $2.36 \pm 0.05$ & $2.11 \pm 0.21$ & $2.04 \pm 011$ & $3.1 \pm 0.10^{*}$ & $2.21 \pm 0.22 *$ & $1.59 \pm 0.31^{*}$ & $1.4 \pm 0.11^{*}$ \\
\hline VSDS & $4.35 \pm 0.30$ & $2.61 \pm 0.05$ & $1.92 \pm 0.10$ & $1.89 \pm 0.20$ & $4.29 \pm 0.21$ & $2.11 \pm 0.31^{*}$ & $1.9 \pm 0.43^{*}$ & $1.89 \pm 0.11^{*}$ \\
\hline \hline
\end{tabular}

Примітка: (р>0,05) порівняно з контрольною групою: 1 - вихідні дані (до розпочатого лікування); 2 - у ранньому періоді після проведеного лікування; 3 - у пізньому періоді після лікування (3 тижні); 3 - у віддаленому періоді (12 місяців).

хірургічного втручання у 78,30 \% пацієнтів відновлення працездатності проходило дещо повільніше з нормалізацією його в пізньому післяопераційному періоді.

Згідно з критерієм VDS, серед оперованих у плановому порядку процес відновлення проходив швидше (96,40 \%) в ранньому післяопераційному періоді, а повне відновлення працездатності впродовж 3 тижнів встановлено у 89,70 \% оперованих пацієнтів.

Згідно $з$ критерієм VSDS патологічних венозних рефлюксів у системі підшкірних вен у ранньому і пізньому післяопераційних періодах не діагностовано в жодному випадку. Лише у 2,30 \% оперованих виявлено неспроможність перформентних вен гомілки через рік спостереження. Утримувалися патологічні венозні рефлюкси із загальної стегнової вени в стегнову вену 238 (41,18\%) пацієнтів, із підколінної вени у вени гомілки у 103 (17,82 \%) випадків. Ця група пацієнтів потребувала динамічного спостереження через високий ризик розвитку рецидиву захворювання.

Оперованим пацієнтам в умовах хірургічного відділення поліклініки виконували спостереження за післяопераційними ранами. Кількість звернень на перев'язки серед оперованих: до 4 перев'язок - 549 (94,98 \%) пацієнтів, до 8 - 21 (3,63 \%) пацієнта, більше 8 - 8 (1,38 \%) осіб.

За період спостереження у 92,20 \% хворих відмічено позитивний результат хірургічного лікування. У 7,80 \% пацієнтів відмічено істинний рецидив захворювання, який підтверджений дани- ми сонографії і потребував повторного операційного втручання, також в амбулаторних умовах. У 2,30 \% оперованих відмічено неістинний рецидив ПХЗВ на оперованій кінцівці, який був усунений методом склеротерапії окремих варикозних гілок на стегні і/або гомілці.

Оперовані пацієнти в післяопераційному періоді впродовж 5-7 днів отримували антибіотики широкого спектра дії в таблетованній формі, венотоніки за “класичною” схемою впродовж 1 місця, компресійний трикотаж (клас компресії 2) терміном 14 днів, знеболювальні середники при потребі в таблетованій формі (нестероїдні протизапальні засоби).

Висновки. Комплекс заходів для лікування первинного хронічного захворювання вен нижніх кінцівок різного класу (за СЕАР) заснований на принципах офісної хірургії, з неускладненою супутньою патологією, зарекомендував себе, ефективний та безпечний метод лікування у 92,20 \% осіб.

Позитивні результати відкритого хірургічного лікування підтверджені низькими показниками післяопераційних ускладнень, рецидиву в ранні та віддалені періоди спостереження, відносно короткими періодами реабілітації, навіть при лікуванні у два етапи при класах $\mathrm{C}_{5}-\mathrm{C}_{6}$.

Окрім цього, вдається досягнути мінімізації фінансових витрат як на проведення операційного втручання, так і на комплекс реабілітаційних заходів для пацієнта та лікувального закладу. 


\title{
З ДОСВІДУ РОБОТИ
}

\section{СПИСОК ЛІТЕРАТУРИ}

1. Распостраненность хронических заболеваний вен: результаты популяционного эпидемиологического исследования / И. Ф. Золотухин, Е. И. Селиверстов, Ю. Н. Шевцов [та ін.] // Флебология. - 2016. - 10 (3). - С. 119-125.

2. Rabe E. Epidemiology of chronic venous disorders / E. Rabe, F. Pannier. - In Handbook of Venous and Lymphatic Disorders. CRC Press. - 2017. - P. 121-127.

3. Adams W. International Association for Ambulatory Surgery (IAAS) / W. Adams // Day Surgery Australia. - 2013. - Vol. 12 (1). - P. 20-21.

4. Franceschi C. Théorie et pratique de la cure conservatrice et hémodynamique de l'insuffisance veineuse en ambulatoire [CHIVA] / C. Franceschi. - Ed. de l'Armançon. - 1988.

5. Franceschi C. The evaluation of essential elements defining varicose vein mapping / C. Franceschi, S. Ermini // Veins and Lymphatics. - 2014. - Vol. 3 (5).

6. CHIVA hemodynamic concept,strategy and results / C. Franceschi, M. Cappelli, S. Ermini [et al.] // Int. Angiol. - 2016. Vol. 35 (1). - P. 8-30.

\section{REFERENCES}

1. Zolotukhin, I.F., Seliverstov, E.I., Shevczov, Yu.N., Avakncz, I.P., Nikishkov, A.I., Tatarinczev, A.M., Kirienko A.I.. (2016). Raspostranennost khronicheskikh zabolevaniy ven: rezultaty populyatsionnogo epidemiologicheskogo issledovaniya [Prevalence of chronic vein disease: Results of a population epidemiological study]. Flebologiya - Phlebology, 10 (3), 119-125 [in Russian].

2. Rabe, E., \& Pannier, F. (2017). Epidemiology of chronic venous disorders. In Handbook of Venous and Lymphatic Disorders. CRC Press.

3. Adams, W.. (2013). International Association for Ambulatory Surgery (IAAS). Day Surgery Australia, 12 (1), 20-21.

4. Franceschi, C. (1988). Théorie et pratique de la cure conservatrice et hémodynamique de l'insuffisance veineuse en ambulatoire [CHIVA]. Ed. de l'Armançon.

5. Franceschi, C., \& Ermini, S. (2014). The evaluation of essential elements defining varicose vein mapping. Veins and Lymphatics, 3 (5).

6. Franceschi, C., Cappelli, M., Ermini, S., Gianesini, S., Mendoza, E., Passariello, F., Zamboni, P.. (2016). CHIVA hemodynamic concept, strategy and results. Int. Angiol., 35 (1), 8-30.
7. Varicose vein stripping vs haemodynamic correction (CHIVA): A long term randomized trial / S. Carandina, C. Mari, M. De Palma [et al.] // Eur. J. Vasc. Endovasc. Surg. - 2008. - Vol. 35 (2). - P. 230-237.

8. CHIVA method for the treatment of chronic venous insufficiency / S. Bellmunt-Montoya, J. M. Escribano, J. Dilme, M. J. Martinez-Zapata // Cochrane Database Syst. Rev. - 2015. - Vol. 29 (6). - P. CD009648.

9. Stripping saphenectomy,CHIVA and laser ablation for the treatment of the saphenous vein insufficiency / J. V. Solis, L. Ribe, J. L. Portero, J. Rio // Ambul. Surg. - 2009. - Vol. 15 (1). - P. 11-14. 10. Lurie F. The 2020 update of the CEAP classification system and reporting standards / F. Lurie, M. Passman, M. Meisner // Journal of Vascular Surgery: Venous and Lymphatic Disorders. 2020. - Vol. 8 (3). - P. 342-352.

11 . Validation of the new venous severity scoring system in varicose vein surgery / S. K. Kakkos, M. A. Rivera, M. I. Matssagas [et al.] // Journal of Vascular Surgery. - 2003. - Vol. 38 (2). P. 224-228.

7. Carandina S., Mari C., De Palma M., Marcellino N.G., Cisno C., Legnaro A., Liboni A., Zamboni P. (2008). Varicose vein stripping vs haemodynamic correction (CHIVA): a long term randomized trial. Eur. J. Vasc. Endovasc. Surg., 35 (2), 230-237.

8. Bellmunt-Montoya, S., Escribano, J.M., Dilme, J., \& Martinez-Zapata, M.J. (2015). CHIVA method for the treatment of chronic venous insufficiency. Cochrane Database of Systematic Reviews, (6).

9. Solis, J.V., Ribe, L., Portero, J.L., \& Rio, J. (2009). Stripping saphenectomy, CHIVA and laser ablation for the treatment of the saphenous vein insufficiency. Ambul Surg., 15 (1), 11-14.

10. Lurie, F., Passman, M., Meisner, M., Dalsing, M., Masuda, E., Welch, H., ... \& Wakefield, T. (2020). The 2020 update of the CEAP classification system and reporting standards. Journal of Vascular Surgery: Venous and Lymphatic Disorders, 8 (3), 342352.

11. Kakkos, S.K., Rivera, M.A., Matsagas, M.I., Lazarides, M.K., Robless, P., Belcaro, G., Geroulakos G. (2003). Validation of the new venous severity scoring system in varicose vein surgery. J. Vasc. Surg., 38 (2), 224-228.

Електронна адреса для листування: prodan@tdmu.edu.ua

\author{
V. M. ANTONYUK-KYSIL ${ }^{1,3}$, I. YA. DZIUBANOVSKYI' , E. F. KUCHERUK ${ }^{3}$, S. A. NEVMERZHYTSKY ${ }^{3}$, \\ A. M. PRODAN ${ }^{2}$, N. A. AL JEHANI ${ }^{2}$
}

Rivne State Humanitarian University ${ }^{1}$

I. Horbachevsky Ternopil National Medical University ${ }^{2}$

Rivne City Hospital ${ }^{3}$

\section{OPEN OFFICE-BASED PHLEBOLOGY OF PRIMARY CHRONIC VEIN DISEASE OF LOWER EXTREMITIES}

\footnotetext{
The aim of the work: to evaluate the effectiveness of the CHIVA technique in the correction of venous insufficiency of varying degrees in an outpatient setting.

Materials and Methods. The results of open surgical treatment of 578 patients (21.45 \% - men and $78.55 \%$ - women) with primary chronic vein disease of the lower extremities were analyzed. There were two groups of patients who underwent planned interventions
} 


\section{З ДОСВІДУ РОБОТИ}

of 423 (71.18\%) patients - group 1 and 155 (26.82 \%) patients in an urgent order - group 2. The distribution of patients by severity of primary chronic vein disease was performed according to the classification of CEAP (2020): C2s- - 355 (61.42 \%), C3s - 159 (27.51 \%), C4s - 38 (6.57\%), C5s - 16 (2.77\%), C6s - 10 (1.73\%). In the structure of group 2, acute thrombophlebitis of the subcutaneous veins of the lower extremities was diagnosed in $143(92.25 \%)$, bleeding from varicose veins - 12 (7.74 \%). The varicose anamnesis of the operated made from 3 to 25 years (on the average (10.4 \pm 5.8 ) years). Bilateral pathology was found in $37.50 \%$ of people, in $62.50 \%$ - unilateral, mainly on the left lower extremity. The degree of clinical manifestations of the disease before and after surgery was assessed using scales (VCSS, VDS, VSS).

Results and Discussion. A comparative analysis of the results of surgical treatment of two groups (emergency and planned treatment) with primary chronic venous disease of the lower extremities in the dynamics of the CHIVA method on the principles of "office-based surgery" showed that the VSDS criterion was normalized in both groups. Among those operated on as planned, this figure was $89.90 \%$ in the early postoperative period. After emergency surgery, $78.30 \%$ of patients recovered somewhat more slowly with its normalization in the late postoperative period. According to the VDS criterion, among those operated on in a planned manner, the recovery process was faster $(96.40 \%$ ) in the early postoperative period, and full recovery within 3 weeks was found in $89.70 \%$ of operated patients. According to the VSDS criterion, pathological venous reflux in the subcutaneous vein system in the early and late postoperative periods was not diagnosed in any case.

Key words: primary chronic venous disease; CHIVA; office-based surgery. 